\title{
Congenital Butterfly Vertebra
}

\section{Vértebra em Borboleta}

Maroua SLOUMA ${ }^{1}{ }^{1}$, Elhem CHEOUR ${ }^{1}$, Héla SAHLI ${ }^{1}$, Mohamed ELLEUCH ${ }^{1}$

Acta Med Port 2016 Jul-Aug;29(7-8):491-491 - http://dx.doi.org/10.20344/amp.6634

Keywords: Lumbar Vertebrae/abnormalities; Lumbar Vertebrae/radiography.

Palavras-chave: Vértebras Lombares/anomalias congénitas; Vértebras Lombares/radiografia.

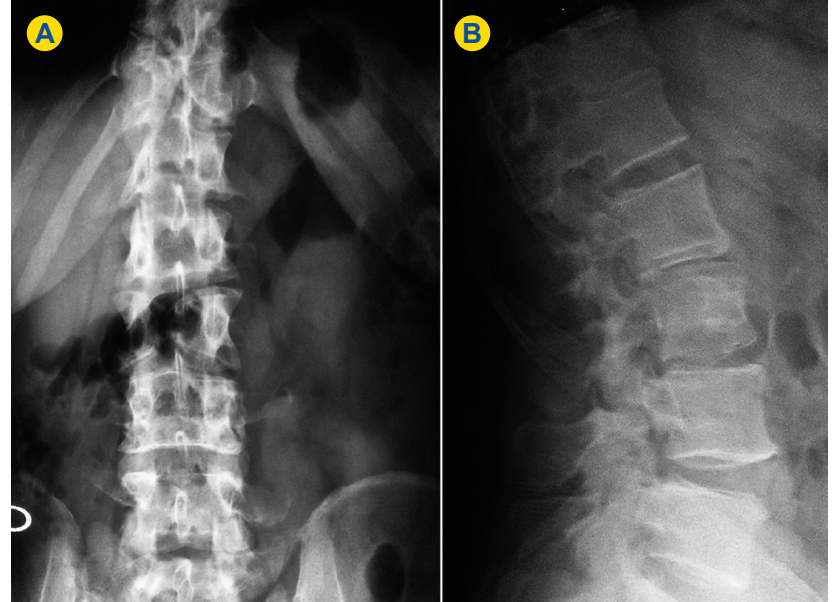

Figure 1 - AP spine $x$-ray showing a sagittal cleft through center of $T 12$ and L3 with funnel shaped ends. A: Lateral $x$-ray of the thoraco-lumbar region showed an anterior wedging of T12 and L3 with widening of its vertebral bodies. B: The adjacent vertebral bodies of T12 and L3 adapt to the altered intervertebral discs on either side by showing concavities along the adjacent endplates, A and B.

A 55 year-old woman presented with constipation and abdominal bloating. Physical examination revealed mild diffuse abdominal tenderness. Abdominal ultrasound and colonoscopy were unremarkable. Abdominal X-ray showed abnormal appearance of T12 and L3 vertebrae. Lateral and anteroposterior radiograph of lumbar spine x-ray showed an anterior wedging of L3 (Fig.1). Computed tomography (CT) showed the aspect of butterfly vertebra (Fig.2). The diagnosis of irritable bowel syndrome occurring in a patient with butterfly vertebra was established.

Butterfly vertebra is a rare congenital malformation, which occurs usually at the thoracolumbar spine. It is due to a defect of fusion of two chondrification centers in an

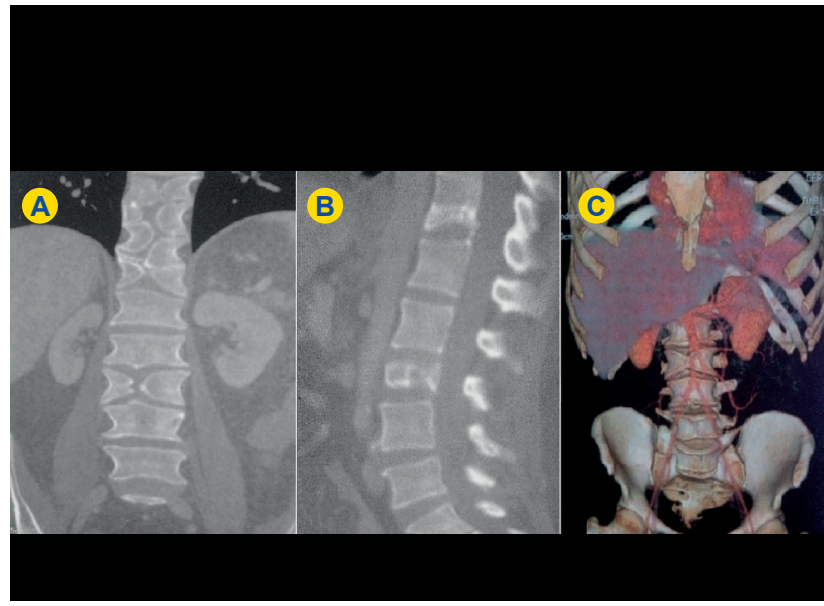

Figure 2 - A: CT scan of the thoraco-lumbar region showing T9T12 and L3 butterfly vertebra; B: CT scan in coronal view revealing butterfly vertebrae at the level of T9-T12 and L3; C: CT 3D reconstruction confirming the presence of butterfly vertebra at L3.

embryonic vertebral body due to a persistent notochordal tissue between them. Butterfly vertebra is commonly asymptomatic. Associations with supernumerary lumbar vertebrae or anterior spina bifida are possible. ${ }^{1}$ Butterfly vertebra can be mistaken with wedge vertebral fracture ${ }^{1,2}$ or, less likely, metastasis. Awareness of this condition assists in making rational use of extensive noninvasive and invasive diagnostic procedures.

\section{ACKNOWLEDGEMENTS}

We thank Miguel Ramalho for his contribution in revising the manuscript.

\section{REFERENCES}

1. Sonel B, Yalc P, Ozturk EA, Bokesoy I. Butterfly vertebra: a case report. Clin Imaging. 2001;25:206-8.

2. Frost C, Mesfin A. Butterfly vertebra mimicking a compression fracture. Spine J. 2014;14:2509-10

\footnotetext{
1. Department of Rheumatology. La Rabta Hospital. Tunis. Tunisia.

$\bowtie$ Autor correspondente: Maroua SLOUMA. maroua.slouma@gmail.com

Recebido: 23 de maio de 2015 - Aceite: 14 de outubro de 2015 | Copyright @ Ordem dos Médicos 2016
} 